\title{
Representing the Past in Exile: The Politics of National History among Burundian Refugees
}

\author{
Simon Turner
}

\begin{abstract}
Life in a refugee camp often brings about the need for explanations among its inhabitants, and historical narratives attempt to supply the answers. But these narratives change over time and several narratives can exist in the same refugee camp simultaneously. This paperargues that the production of historical narratives is closely related to the dominant political ideologies in the camps. It argues that in order to understand the changes in representations of the past in the camps, one must analyze the changes in political movements among the Hutu opposition. It shows how the dominant discourse on ethnicity in Burundi has changed since the early 1980s and how this has forced the Hutu opposition to reformulate its demands. Finally, it contends that regional developments, such as the genocide in Rwanda, have also been influential in the general shift from an essentialist to a pluralist discourse among Burundian Hutu in exile. It concludes that ideological formations among refugees in camps are in no ways isolated from the outside world.
\end{abstract}

\section{Précis}

La vie dans un camp de réfugiês crée souvent des conditions quiamenent ses habitants à recourir à l'explication, et les narrations historiques tendent a fournir les éléments explicatifs recherchés. Mais ces narrations changent avec le temps et plusieurs dispositifs narratifs peuvent exister dans les même camps de réfugiés simultanément. Cetarticle présente une

Simon Tumer is a Ph.D. candidate and Research Fellow, International Development Studies, Roskilde University, Roskilde, Denmark.

The author would like to thank the following people for guiding me through some of the thoughts behind this paper: James Ferguson, Thomas Hansen, Barbara Harrell-Bond, Steffen Jenisen, Liisa Malkki, Marc Sommers, Finn Stepputat, Lone Turner, and Eftihia. Voutira. argumentation selon laquelle la production de narrations historiques estétroitement reliée à l'idéologie politique dominante dans le camps. On soutient que pour comprendreles changements de représentations de la vie passés du camps, on doit analyser les changements inhérents au mouvement politique del'opposition Outoue. On montrealors combien le discours dominant sur l'ethnicité au Burundi a changé depuis le début des années 1980, et comment cephénomènea forcé l'opposition Outoue à reformuler ses demandes. Finalement on avance que les développements dans la région, comme par exemple le génocide rwandais, ont eu aussi une forte influence dans le mouvement général de passage d'un discours essentialiste d̀ un discours pluraliste parmi les Outous burundiens en exil. L'article conclut queles formations idéologiques se développant entre réfugiés dans les camps ne sont en rien isolées du monde extérieur.

\section{Introduction}

This paper examines the relations between the production of historical narratives and political movements in refugee camps. After finding that competing versions of Burundi's past exist among Hutu refugees in camps in Tanzania and that these versions of history have evolved over the years, this paper contends that these narratives do not merely "emerge" as a result of objective life conditions in the camps-although these conditions can be more or less conducive to their survival. Rather, representations of the past make up part of larger ideological constructs that are linked to the main political movements in the camps. Thus in order to understand the production of historical narratives we must analyze the wider political framework that refugees are part of. This framework extends far beyond the confined space of the refugee camp; involving national, regional and global changes in the political field. ${ }^{1}$

\section{Two Narratives}

We are sitting on narrow wooden benches in a neat hut made of UNHCR plastic sheeting - the white and blue material that dominates the landscape in Lukole refugeecamp and much of the surrounding Tanzanian villages. We are in "La Vedette," one of the more expensive restaurants that have shot up in the camp. Here, the elite enjoy brochettes, Pepsi and Primus-beer smuggled in from Burundi. Opposite me a young man with enthusiastic pale brown eyes is explaining to me the intricate details of mwamiship and Tutsi trickery and dominance in pre-colonial Burundi. He explains about all the different dynasties and lists their names. He tells me how the Tutsifirst came to Burundifrom the North with their cattle, and how they cunningly lured the Hutu into bondage through lending them calves or playing on the superstitious nature of the Hutu.

He explains how the Tutsi are not honest and hard working like the Hutu. Their success has been achieved through cunningness, lies, and secrecy. If they were not so secretive, the Hutu would discover their falseness and that would be the end of Tutsi power. That is why the Tutsi doeverything that stands in their might to prevent Hutu from being educated and discovering the "Tutsi secret." You cannot trust a Tutsi and therefore they are not allowed to join his party, Palipehutu (Parti pour la Libération de Peuple Hutu).

Some of the stories he tells me with passion and oratorical eloquence-in spite of his having only primary education, and in spite of (or perhaps because of) being born in exile-and they are quite fascinating as stories.

In theold days they would choose the most beautiful young Hutu men and women. They would go to the fami- 
lies and say "this one is beautiful and strong-this one also." Then they would lay them down like this-in rows on the ground-on the path. This was at certain celebrations for the Mwami [king]. Then the royal cattle would walk along them-on their backs, like that, over their bodiesdown to the watering hole ... (Young man, Lukole, September 1997).

The next day I am sitting the same place, interviewing a group of menyoung and old-who all hold some position of importance in the camp. One is a head teacher, another works for an NGO, one used to be an officer in the army, another a burgomaster. The reason, they are here, is that they are the leading figures in Palipehutu's rival party in the camp; the CNDD (Conseil National pour la Défense de la Démocratie). With the memory of the stories from the previous day in mind, I try to ask them about Burundi's past, and being educated and interested in politics and the affairs of their country, they answer. But there is no doubt that theenthusiasm for ancienthistory is not overwhelming. They manage to present the various dynasties of Burundi but they do not spill over with detailed accounts of royal cattle walking on young Hutu or royal drums made of the skins of Hutu testicles. For them pre-colonial history has only academic interest. They believe the conflict between Hutu and Tutsi only started after colonialism. It was the Belgians who, through a policy of divide and rule, created the tensions between Hutu and Tutsi.

\section{Constructing Histories in Exile}

These two narratives illustrate to us how differently the past can be represented. One believes the ethnic conflict to be age old and between two essentially different races, while the other believes the conflict to be the result of colonial policies and the categories to be constructed to some degree. While the young Palipehutu man is obsessed with ancient history and presents a very coherent nationalhistory, the CNDD supporters are more interested in recent history and often contradict themselves.
Before looking at the concrete construction of the past in Lukole, some theoretical clarifications on the relations between history, ideology and political movements are needed. History and its representations in exile-or anywherefor that sake-arenotmerely a question of recounting facts from the past. Especially when we consider the history of nations we are dealing with constructs; constructs that are creating a nation and a national history retrospectively. As Balibar writes,

The history of nations, beginning with our own, is always already presented to us in the form of a narrative which attributes to these entities the continuity of a subject. (Balibar 1991, 86)

The nation as a continuity is a twofold illusion. It is the illusion that generations have handed down an unchanged "substance" over the centuries. And it is theillusion that the contingency of events thatmake up history are not contingent at all; there could only have been this one chain of events. It is the illusion of a national destiny (Balibar 1991, 86-87).

The right to tell this national history is a highly contested domain in Burundi. All parties to the conflict are eager to tell "the truth" about what actually has happened and is happening in their country. Everyone believes $h^{2}$ possesses the "substance" of the national heritage. In the camp, people often wanted me to take their story to "the important people of the UN and your country" so that the "reality" could get out. All Hutu refugees agree that the Tutsi are secretive and stick to power through "hiding the truth." If only this "truth" could get out and the Tutsi secrets be exposed, they argue, the outside world (especially America) would help solve the conflict. ${ }^{3}$ These views are all permeated by the illusion of a national destiny.

Liisa Malkki (1995), in Purity and Exile: Violence, Memory and National Cosmologyamong HutuRefugees in Tanzania, provides a brilliant analysis of historical narratives in exile. Like the young Palipehutu supporter, mentioned above, the Burundian refugees in
Mishamo refugee camp were very preoccupied with their past.

In virtually all aspects of contemporary social life in the Mishamo camp, the Hutu refugees made reference to a shared body of knowledge about their past in Burundi. Everyday events, processes and relations in the camp were spontaneously and consistently interpreted and acted upon by evoking this collective past as a charter and blueprint. (ibid., 53)

However, as Balibar points out such histories are not merely descriptions of the past. They are a means to better understand the present.

It [the Hutu history] represented, not only a description of the past, nor even merely an evaluation of the past, but a subversive recasting and reinterpretation of it in fundamentally moral terms. In this sense it cannot be accurately described as either history or myth. It was what can be called a mythico-history. (ibid., 54, original emphasis.)

How much mythico-histories are fact or fiction, how much they tell the "true" history of Burundi, is irrelevant, Malkki argues.

But what made the refugees' narrative mythical, in the anthropological sense, was not its truth or falsity, but the fact that it was concerned with order in a fundamental, cosmological sense. (ibid., 55)

Malkki's work shows how refugees, whose world has crumbled, following massacres of horrific proportions and brutality and exile to a very different environment, are very much in need of new explanations as to why they are where they are. She also shows how self settled town refugees do not appear to have the same urge to create new national histories.

But whereas mythico-histories seem to simply "emerge" in her analysis, I believe that these histories are actively used and manipulated for political means. As we saw in the twointerviews, two very different versions of national history cain exist in the same refugee camp. In other words, the versions of what happened in Burundi as told to Malkki in Mishamo and tome in Lukole 
make up part of larger political discourses and have been sanctioned by the political leaders in the camps or elsewhere.

The question of whether mythologies and ideologies merely emerge on the basis of structural conditions in society or can be manipulated by political actors, has always been a point of debate for political scientists. ${ }^{4}$ In what he calls "the Dialectic of'Availability' and 'Structured Contingencies' (Hansen 1997, 119) Thomas Hansen argues that

The success or failure of political movements and parties is, thus, heavily conditioned by the structure of 'availability'-i.e., a certain level of disgruntlement, a sense of violation of rights and readiness to protest in an electorate or population-that provides necessary but far from sufficient, conditions of possibility for political mass-mobilization ... Further, the success or failure of a political actor depends on the attractiveness of the interests it claims to represent ... (ibid., 164)

Thus the contents of the mythico-histories, the rumours, and the nationalist and political ideologies that circulate in the camp cannot be deduced from the objective interests nor the objective life conditions of the refugees alone. One cannot a priori determine which ideologies will emerge. But for ideologies to gain some ground-to find resonance among the refugees-they must appeal to the refugees. They must offer an explanation as to why they are in a refugee camp and offer themselves as the solution to all their troubles and tribulations. 5

Furthermore, as much as these ideologies promise to fulfil a need in the camps, they might have their origins elsewhere. If political movements are to have any success and credibility, they mustalso be able to relate to the political playing field in the country of origin as well as globally. Thus, in onder to understand the dynamics of political ideologies in the refugee camps one has to expand one's analysis to political dynamics far beyond the camp.

As Marc Sommers (1995) points out, the educated, male Hutu elite in exile claims to represent all Burundian refu- gees, often playing the ethric card in order to further its own political interests, without really caring about the watu wadogo (small people). There is no doubt that Burundi society is deeply hierarchic, ${ }^{6}$ and I would often hear comments about "big men" as opposed to the "peasants" in the camp. But the fact that refugee society is hierarchic and that certain "big men" get to represent the refugees as such does not automatically entail that this is a "wrong" or "false" representation. As mentioned above, the ideologies of the elite have to "appeal" to the "small people" to gain support, no matter whether they actually represent their objective interests.?

There might well be counter discourses among the women and the poor in the camps that I have not encountered. As Sommers also remarks, "For most Burundi refugees, public silence is the safest strategy for survival" (ibid., 23). I also found that non-elite refugees-especially women-were not very comfortable with expressing their opinions to me in public. However, in life history interviews with young, nonelite men, they would usually open up And usually they would express opinions about Burundi history that corresponded with either Palipehutu's or CNDD's versions. As we will seelater in this paper, the most obvious diversion or resistance to elite politics is expressed by businessmen in the camps who prefer to concentrate on the present in the camp rather than on the past and future in Burundi. It is difficult to estimate how much these political ideologies represent the "small people" but it is certain that they are the dominant ideologies in the camp and that they are very important for understanding how refugees understand their past.

In conclusion, we may claim that representations of the past make up part of political ideologies in refugee camps, and for these ideologies to have any thrustamong refugees they mustappeal to the refugees and offer themselves as the solution to all their problems. They do not necessarily reflect what an outsider would consider the objective interests of the "small people", but this does notdisqualify them as powerfulideolo- gies, that can mobilize and be internalized by the "small people."

These politicalideologies do not only relate to the problems of the refugees. They also have to respond to and adapt to changing political agendas in Burundi. In order to understand the concrete changes in ideologies and constructions of the past in Lukole, we must analyze the contexts in which the various political movements were created and evolved.

\section{The 1972 Massacres: An Eye-Opener}

In 1972, an estimated 100,000 Hutu were killed by the Burundi army (Lemarchand 1989, 22), and it is estimated that some 150,000 Hutu fled the country and settled in refugee camps in Tanzania (Lemarchand 1996, 104). In 1972 all ethnicity was denied discursive existence by the Tutsi dominated Burundian government. The official discourse held that the terms Hutu and Tutsi were "false" colonial tags that had been put on Burundians by the Belgians in order to divide and rule. With independence, they argued, the false divisions of the Burundi people had seized to exist, and should therefore not be mentioned. Those who mentioned ethnicity were not only guilty of tribalism and of splitting the nation, they were also traitors to the nation, since unity was a defining element of the nation itself.

Even among the opposition in Burundi ethnicity was hardly an issue prior to 1972. But the massacres in 1972 functioned as an eye-opener to the surviving Hutu, especially those in exile. Many refugees related to Malkki how they had started to talk to other refugees in Tanzania and in this way had learned about the extent and scale of the massacres. "We realized that we were all here for one reason: because we are of the Hutu group" (Malkki 1995,111). The refugees from 1972 had very littleeducation and had not previously been politically organized. In fact, they had hardly even thought of themselves as Hutu. Experiencing the extreme cruelty of the massacres and later living in an isolated camp, created theneed for explanations; 
explanations that they did not have ready madebefore they fled. Their experience of one cosmology cracking and the need to create a new musthave been acute. This was the perfect place for radical political parties like Palipehutu to start "awakening the masses."

Palipehutu was created in Mishamo in April 1980. It conducted an "awareness campaign" first in refugee camps in Tanzania and Rwanda, later inside Burundi itself. It is said that Remy Gahutu, founder of Palipehutu, purposefully chose Mishamo as the place to start "educating the people" because Mishamo was in the middle of virgin forest, and people did not have much contact with the outside world. Ulyankulu, on the other hand, was placed next to a railway line, and its inhabitants were much to busy trading to be bothered with politics and their national history. ${ }^{8}$ The ideology that he brought gave them all the answers to their questions. It offered an answer to their questions of why they were there. With the lack of other explanations and solutions, Palipehutu's ideology soon became hegemonic and its version of history the official and only legitimate one. Remy Gahutu declares in the Preface tohis book "Persecution of the Hutu of Burundi":

We urgently demand that the Hutus of Burundi who read this book teach their children the exact truth about their subjugation. The goal of this document is to remove the misunderstandings and falsifications of Burundian history that have been encouraged by certain corrupt members of the blood-soaked Tutsi regime ... (Gahutu, no date, 1 ).

So, as much as we may envisage that mythico-historiesmerely "emerge" and become standardized and authorized versions of specific events, we must also be aware of the political power structures in the campat their time of production. ${ }^{9}$

The discursive elements of Palipehutu's discourse were created in opposition to the dominant discourse in Burundi at the time. Therefore, its primary goal was to prove that Burundi was indeed inhabited by several ethnic groups. Once it had been established that such ethnic groups exist-and have existed since time immemorial-it could also argue that the Hutu were essentially exploited.

In the above mentioned-almost programmatic-document by Remy Gahutu, key words are liberation, people's party, unity, awaken the Hutu consciousness, and the like. Many of these remind of socialist jargon of the Fanonistbrand: It is the nobleduty of the avant garde to educate the masses and make them aware of their oppression. In a chapter named "What can be done to save the Hutu" the various subtitles, giving us the answer, are as follows: "A. The Hutu Must Become Aware of the Causes of Their Suffering, B. Hutu Unity, C. The Foundation of a Combative Party,D. The Necessity for Dynamic Leadership, E. What Is at Stake in the Hutu Demands, F. The Hutu Must Avoid IdeologicalQuarrels." Again, we see how awareness and unity are the prime means to achieve the goals.

The book is also heavily loaded with nationalist discourse. In the first section of the chapter, mentioned above, Gahutu reflects on the Hutu nation:

A close examination of the situation in Burundi show [sic] that the Hutu have lost a country which was rightfully theirs ... For a people to struggle, retake their country, and emerge victorious, their primary concern must be to strengthen their own identity ... Some Hutu ... have changed their ethnic identity in order to try to improve their social status by rejecting their own people. These turncoats are only fooling themselves, because the Tutsi have never truly accepted them into their ranks.

(Remy Gahutu, no date, 49)

Gahutu clearly sees the struggle as a nationalist one. The Hutu have a country which is rightfully theirs, only it has been stolen from them by someone else; the late comers and colonizers; the Tutsi. Again the task of Palipehutu cadres is to make the Hutu aware of this fact and of their true, authentic, identity. Those whodeny this identity, the "turncoats," are not only traitors to the cause, they are also fooling themselves; they will never be happy, as long as they deny their authentic identity. This idea of a true identity, that cannot and shall not be attempted hidden, and of a Volk, that belongs to a nation, is typical of the kind of Blut und Boden nationalism, as it was formulated by the German romanticist, Herder, in the last century.

During the 1980s Palipehutu enjoyed a lot of popular support, especially in refugee camps, being the only opposition party of significance. In the last few years its support seems to have dwindled, although it is almost impossible to obtain reliable facts on the subject. ${ }^{10}$

We may conclude that the dominant national histories among Burundi refugees in camps in the 1980 s coincided with the ideologies of Hutu parties, bom in exile. These ideologies related to the feeling of despair felt by many refugees. They also related to the discursive power-field in Burundi where themain aim of the Hutu opposition was to prove the existence of an ethnic Hutu group.

\section{From Essentialism to Pragmatism?}

Many of the refugeesin Lukolehave left these ideas for ones that are less essentialist and mostly coined in the terms of liberal democracy. The Hutu Nation is rarely mentioned, it is difficult to get a refugee today to tell you the anatomic differences between Hutu and Tutsi, and "liberation" is now replaced by "democracy." Before exploring the content of thenew ideologies in Lukole refugee camp, let us shortly look at some of the political developments that took place in Burundi between 1972 and 1993, and how they relate to the Hutu opposition's room for manoeuvre.

The official discourse of the government remained much the same formany years. A Tutsi élite, mainly from the Hima clan and Bururi province, dominated the government and the armed forces. Officially, ethnic groups still did not exist in Burundi, and anyone who fought for Hutu rights was accused of tribalism and of trying to destroy national unity.

However, pressure mounted-especially from international donors-to reform the government, and Major 
Pierre Buyoya-president since 1987started reforms towards multi-party democracy. Freedom of expression was greatly secured and there were many debates throughout the country (Reyntjens 1995, 9). Committees (consisting of equal numbers of Hutu and Tutsi) were created and conferences were held to debate "the question of National Unity". Obviously, the government was still determined to portray Burundi as a unity without ethnic divisions but the realities on the ground and the mounting pressure from the Hutu opposition were forcing the government to consider what it called the "diverse component parts of the Burundian population." (Charter for National Unity, Article 84, quoted from Reyntjens 1995, 9).

Finally, in 1992 a multi-party system was in place, and in June 1993 an overwhelming majority of the population voted Frodebu (Front des Démocrates du Burundi) into the National Assembly and its leader, MelchiorNdadaye, a moderate Hutu, in as president. As we may recall, this government did not last long. With the assassination of the president a few months later, the country was thrown into a carnage of killing once more. ${ }^{11}$

So what did these two decades do to the Hutu in Burundi and to their ideologies? Firstly, the 1972 massacres were a "watershed event" (Lemarchand, 1996) for those who remained in the country as well as the refugees, and it came to have great impact on their attitudes. During the late eighties and early nineties Palipehutu began to operate inside Burundi. They operated clandestinely and started awareness campaigns like in the camps. By the time Buyoya legalized political parties, many Hutu were well aware of their history, thanks to Palipehutu cadres. However, Palipehutu itself was never legalized and most of its supporters chose to support the moderate Frodebu in the elections. Frodebu members have expressed to me their gratitude towards Palipehutu for making them "aware."

Nevertheless, Frodebu differed from Palipehutu in many ways. Given the new rules of the playing field in an open democratic atmosphere, Frodebuhad to play by these rules, as opposed to Palipehutu that was used to operating under quite different rules. Democracy and human rights had become the code words that replaced liberation and unity. They were the new nodal points, as Laclau would have it, around which chains of equivalence and antagonisms could be articulated. And after the 1993 coup it was the restoration of democracy that became the key issue for the Hutu opposition and hence the Hutuin exile. If only democracy in the liberal sense of the word, understood as multipartyism, could be re-installed, every Hutu would be happy, and Burundi would again experience peace and prosperity for everyone. When interviewing refugees, I would often ask them, whether this would be enough. Wouldn't there still be a lot of hatred? But they would shrug off my doubts.

Since the vast majority of Hutu voted Frodebu in 1993 the vast majority continued to support its successor - the CNDD-in exile. Thus most refugees, arriving in Tanzania in 1993-94-as opposed to the ones from 1972-already felt that they belonged to a party, making recruitment to other parties, such as Palipehutu, more difficult. CNDD was created by Leonard Nyangoma and other Frodebu members who found that the remaining Frodebu leadership was giving too many concessions to the small but active and increasingly radical Tutsi opposition. ${ }^{12}$

The attitude towards the Tutsi becomes more ambiguous in this discourse. Whereas the Palipehutu supporters in Mishamo had no doubt about the malignity of the Tutsi, nor about their "racial" differences, both physically and mentally (cf. Malkki 1995, 78-80), the refugees in Lukole are more ambivalent.

Most CNDD members in Lukole would go to great lengths to explain that there are no differences between Hutu and Tutsi. However, this discourse on Hutu-Tutsi relations was often contradictory. For although there is no difference between a Hutu and a Tutsi, you can always tell the difference after some days on theirbehaviour. Similarly, they would explain that there are no physical differences, not because there areno specific Hutu or Tutsi traits, butbecause you get Hutu with Tutsi traits and vice versa. Once I let some educated friends in the camp, who had explained that there are no differences in appearance, look through abook of mine on Burundi history. Then suddenly one said to the other "Tutsi kabisa [a real Tutsi]" and pointed to a photo (I think of Prince Rwagasore), and they both laughed and pointed. When I asked what the fuss was about, they answered that he looked so obviously like a Tutsi, although they could not explain how.

Similarly, the interpretation of history becomes more ambivalent. There seems generally to be less of an obsession with ancienthistory. When I would ask refugees when the problems between Hutu and Tutsi arose, the answer often would be; at independence, in 1965 when the first Hutu prime minister was killed, or in 1972 . So, officially at least, they actually adhere to the same national history as the Burundi regime; namely that Hutu and Tutsi lived in harmony until they were colonized by the Belgians.

This ambivalence may date back to the time of democratic reforms. The government itself no longer stuck vehemently to the idea that no ethnic groups existed. It had admitted to the idea of "component parts." Nevertheless, political parties were strictly not allowed to use ethnicity in their programs. This ambiguous stance on behalf of the government was reflected in the opposition. On the one hand the whole struggle had been for the rights of the Hutu. On the other hand Frodebu was very careful to avoid being seen as an ethnic party, knowing very well that the governing Uprona party would seize the opportunity to accuse Frodebu of being tribalist.

Another reason for the most of the refugees in Lukole to seem less essentialist has to do with their acute awareness of the global community. ${ }^{13}$ Refugees in Lukole would hear BBC, VOA, RFI and South African radio as well as Tanzanian, Burundian and Rwandan radio, and if they did nothave a receiver or could not understand Eng- 
lish, French or Swahili, they would get the news from others. Hence they all know what the international community is preaching in Africa (democracy and human rights) and they know what the international community says about the events in Rwanda in 1994.

As most scholars on the Great Lakes region have commented, one cannot fully understand the dynamics of Burundi without knowing the dynamics of Rwanda and vice versa. The same goes for understanding the politics of Hutu opposition in Burundi now. They are aware that to avoid international opinion against them, they must avoid being associated with the Hutu genocidaires from Rwanda. Therefore CNDD members are very careful not to mention anything that might sound like Hutu supremacism. In the introduction to his book Burundi; The Origins of the Hutu- Tutsi Conflict, Leonce Ndarubagiye,a TutsimemberofCNDD, exiled in Nairobi, warns against comparing "the situations of Rwanda and Burundi solely on ethnic terms... the policy of Hutu of Burundi has nothing to do with that of Rwandese Hutu" (Ndarubagiye 1996, xiii)

From this we may conclude that the shift in the dominant discourse in Burundi, involving democratic reforms and a partial accept of ethnicity, changed the political playing field, forcing the Hutu opposition to change its ideology and reformulate its resistance around issues of democracy and human rights. Another reason for abandoning essentialist and ethnicist cat egories can be found in the fear among Burundian Hutu of being compared with the genocidaires of Rwanda.

\section{Politics and History in Lukole}

Exploring politics in the refugee camp is a daunting task. Political activity is strictly not allowed by the Tanzanian Ministry of Home Affairs (MHA) as this might jeopardize the already strained relations between Tanzania and Burundi. After being in the camp for some time, people did, however, open up to me and tell something-albeit not all-of what was going who fled immediately after Ndadaye's assassination, were often either educated or held some political office as Frodebu members (among them a few burgomasters). They fled because they elt personally threatened. Other refugees arrived in 1995, fleeing from fighting between rebels and government troops in Giteranyi Commune just across the boarder. They were usually uneducated peasants fleeing en masse from the fighting. They were originally kept in a different refugee camp and were moved to Lukole in early 1997.

It is widely agreed among the refugees that the 1993-94 refugees are overwhelmingly Frodebistes / CNDD supporters, while Palipehutu still enjoys some support among the later arrivals. It is difficult to estimate how much this is

true and how much it is rumours, as all political activity is clandestine. Equally there are many local theories as to why this is so. From my observations, however, there seems to be a correlation between time of arrival and politica alliance. The Frodebu leaders that fled in 1993-94 naturally took their politica ideas with them and consolidated their power in Lukole-often becoming stree leaders, NGO employees, or security guardians. The later arrivals had experienced a climate of ethnic radicalization in Burundi from 1993 until they fled in 1995-96. They were thus more "available" to radical poli tics. Furthermore, as far as I have been able to gather, the rebels fighting in their commune were Palipehutu. And as they were put in a separate camp at first, the established leadership in Lukole could not manage to rein them in time.

Finally, letus remember that not everything in the camp is related to politics, nor is everyone interested in politics. Neither are they very interested in the history of their country. There are other ways of coping in exile; other strategies to feel a sense of meaning in life. Young men especially will spend all their time and energy trying to accumulate a little extra money by running all sorts of bus iness; from bicycle taxis to trading in USAID maize rations and running bars and video halls.14 This strategy is focussed on the present and their own immediate benefits for themselves and their families in the camp. National history does not interest them much, and politics will just get you into trouble. Thus we find a dichotomy between those refugees who try to understand the past and change the future of the Hutu people as a whole, and those who invest in the present and their immediate family. 15

\section{Conclusion}

This paper has attempted to explain how different versions of the past are generated and become sometimes "the" legitimate version in certain contexts. The reason for going into this was the discovery of totally different versions of history among Burundian Hutu in Lukole refugee camp.

There is no doubt that the social conditions of the refugees in exile playa big role in shaping their understanding of national history. As Malkki pointed out, there was an abysmal difference between the refugees living in Mishamo refugee camp and those living in Kigoma town, when it came to their understanding of and interest in their common past. Similarly there are differences between most of the refugees in Lukole in the late 1990s and the refugees in Mishamo in the 1980s.

As Malkki so rightly notes, the mythicohistory is a cosmology. It helps explain to the refugees why they are where they are. But this process of creating a national history and hence a nation is no innocent game. It takes place in a complicated power field and inserts itself and asserts itself in that field. Therefore this paper has attempted to analyze this power field. We have seen how the hegemonic discourse in Burundi-partially due to global changes and partially due to resistance within the country-had to shift in the late 1980s and early 1990s. This shift in the hegemonic discourse resulted in a shift in the possibilities of resistance. Resistance had to be formulated around other issues, other nodal points. Consequently, the main opposition Hutu party of the 1990s, Frodebu, has a some 
what different ideology to the main party of the 1980s, Palipehutu.

Whereas Palipehutu emphasizes liberation, nationalism, and Hutu unity, Frodebu emphasizes human rights and democracy. Apart from these differences, Palipehutu is more preoccupied with history. Its supporters share a cosmology that is "at once compelling and frightening" (Malkki 1995, 258).

Notmany refugees in Lukole seem to know of these mythico histories. Their version of national history is pragmatic and in many ways contradictory and flawed. The reasons for contradictions could be due to the essence of pragmatic histories; they are not fully fledged, coherent cosmologies. There could also be contradictions because of the inherent contradictions in the political ideology of Frodebu.

In Lukole both Frodebu and Palipehutu have supporters, and allegedly Frodebu is much bigger than Palipehutu. The question is whether Frodebu's pragmatic version of national history will remain dominant. As we saw, the historical changes in the power field in Burundiproved advantageous for Frodebu, and it was difficult for Palipehutu to spread its ideology in the camp. But can a pragmatic history survive in a refugee camp for long if it is up against a beautiful and dangerous mythico-history; a history that appeals through its clarity and strength? Will the radicalization of politics inside Burundi not call for more radical national myths in the refugee camps as well? Will the strength of the Frodebu leadership and the physical setting of the camp, with its abundance of traders, be able to keep Palipehutu at bay? Or willFrodebu itself start sliding towards a more essentialist, ethnicist ideology? The future of national histories in Lukole is in no ways certain.

On a more general level, this paper has shed light on how the political field greatly influences which histories and cosmologies refugees believe in, and how objective life conditions in or outside of camps certainly influence but cannot explain the emergence of specific ideologies. Finally, while refugees certainly are constrained and condi- tioned by life in camps, we must not presume that they are isolated from the outside world; the changing relations of power in their country of origin, regional geopolitical developments, and global trends are all monitored and interpreted by people living in refugee camps. All this information is processed into rumours and myths and interpreted according to the available ideologies in the camp. During this process some ideologies may have to change or give way to others, as has happened-and is constantly happening-among Burundian refugees in Tanzania.

\section{Notes}

1. This paper is based on a year's field work in Lukole, a camp for Burundian refugees in Tanzania, and makes up a small part of a research project with the primary objective of exploring how young men adapt to life in a refugee camp.

2. The right to tell the history of Burundi or to have any political opinion is virtually reserved for men.

3. This conflict over the true nature of the conflict in Burundi has also spread to the academic world, making it very difficult to manoeuvre withoutbeing accused of being pro-Hutu or pro-Tutsi. This is what René Lemarchand has termed "the meta-conflict" (Lemarchand 1996, 17-33).

4. Without going into too much detail here, my understanding of the relation is inspired by Slavoj Zizek (Zizek 1989) and Emesto Laclau (Laclau 1994) and their reading of Lacan in political analysis.

5. In Lacanian terms, ideologies promise to suture the rift that prevents the community from being what it ought to be.

6. Similar obedience to the leaders has been attributed a significant role in organizing the genocide in Rwanda in 1994 (Cf. Prunier 1995).

7. We encounter a similar debate on the "intimidators" in the camps for Rwandan refugees in Tanzania and Zaire. If we accept that "civilian" refugees actually believed that the Tutsi would kill them upon return, the issue of intimidators becomes irrelevant. Such people donotneed intimidating.

8. This information is based on interviews with refugees in Lukole, some of whom had lived in Mishamo and Ulyankulu, and with Etienne Karatase, (former?) leader of Palipehutu.
9. Of course, politics should bevadenod in broader terms than party politics. How. ever, for the simplicity of the argument I have chosen to focus on party politicintive camps. This choice is also due to the ovewhelming presence of party politics found in the camp.

10. All parties claim much larger support than they have, and like to take the honour for any rebel activity in Burundi. However, even Palipehutu supporters do talk of the problems that they now face compared with the "good old days" of Remy Gahutu.

11. For competent analyses of what Reyntjens has termed "the most successful aborted coup in history" (Reyntjens 1995, 16) see Lemarchand (1996) and Reyntjens (1995).

12. In May 1998 a splitoccurred in CNDD with the former chief-of-staff Jean-Bosco Ndayikengurukiye claiming to be the new leader and becoming the leader of what is now known as CNDD-FDD.

13. There is no doubt that my being conceived of as a part of international opinion, or at least a link to the international community, biased the stories that were presented to me. However, it is still interesting to note that they knew in which way to censor the information that was given to me, i.e., to leave out essentialist, ethnicistopinion and replace it with the rhetoric of democracy and human rights.

14. I discuss the changing roles of young men in the camps in Angry Young Men in Camps: Losses and New Opportunities (forthcoming).

15. This is reflected in their attitudes towards education. The politicized elite will often see education not only as a way of augmenting ones personal chances in life. It is alsoan investment in the future of the Hutu people. Traders, on the other hand, will dismiss this and (rightly) claim that educated Hutu always are the first to be decapitated in Burundi.

\section{References}

Balibar, Etienne. 1991. "The Nation Form: History and Ideology." In Race, Nation, Class, Ambiguous Identities, edited by $\mathrm{E}$. Balibar, and I. Wallerstein. (London \& New York: Verso).

Gahutu, Remy. No date. Persecution of the Hutu of Burundi. Translated from French by Hugh Hazelton and Peter Keating. Design and Production: Productions Paperasse.

Hansen, Thomas. 1997. The Saffron Wave; Democratic Revolution and the Growth of Hindu Nationalism in India. Vol. 1, The Democratic Revolution. Dissertation Paper no.1, International Development Studies, Roskilde University. 
Laclau, Emesto. 1994. "Minding the Gap." In The Making of Political Identities. London \& New York: Verso.

Lemarchand, Rene. 1989. "Burundi: The Killing Fields Revisited." Issue: A Journal of Opinion 18, no. 1.

Lemarchand,Rene.1996. Burundi, EthnicCon flict and Genocide. Washington, DC: Woodrow Wilson Center Press; New York, NY: Cambridge University Press.

Malkki, Liisa. 1995. Purity and Exile: Violence, Memory, and National Cosmology among Hutu Refugees in Tanzania. Chicago \& London: The Tanzania. Chicago \& Lniversity of Chicago Press.
Und

Ndarubagiye, Leonce.1996. Burundi: The Origins of the Hutu-Tutsi Conflict. Nairobi, Kenya.

Prunier, Gerard. 1995. The Rwanda Crisis: History of a Genocide. New York: Columbia University Press.

Reyntjens, Filip. 1995. Burundi: Breaking the Cycle of Violence. Minority Rights Group Report, London.

Sommers, Marc. 1995. "Representing Refugees: The Role of Elites in Burundi Refugee Society." Disasters 19, no. 1. Zizek, Slavoj. 1989. The Sublime Object ofIdeology. London and New York: Verso. :J

\section{Breaking Ground:}

Thel9S6Hungarian Immigration toCanaaa

\section{Edited by Robert H. Keyserlingk}

Toronto: Y()tkLanesPress, 1 3; ISBN 1-550 14-232-1;

$$
117 \text { pages; } \$ 6.99
$$

This bOQ,kis a(;ollec: ion ofper\$(mal and :trc:hiY;II-based memories 011. the selection, transport and settlemeht of about 40,000 Hungarian refugees in Canada in one year. It is a source of primary record as well as scholarly reflection on one of the most significant refugee. movements to Canada after World War II-tb.e J956 Hq.ng.u:iall refugee.. movement.

Based on papers that were presented at a 1990 conference, the authors touch on the unique political, administrative and settlement features of this movement.

The resulting work, edited by Professor Keyserlingk, is a unique mix of personal reminiscencesandac:ademicscholatship.

\section{Available from: Centre for Refugee Studies F (416\}}

736-5837 ...Email: refttge@yorku.ca

\section{Asylum: A Moral Dilemma}

\section{ByW.Gunther Plaut}

Toronto: York Lanes Press, 1995; ISBN 1-55014-239-9; 192 pages, indexed; \$19.90.

Every year the refugee landscapec:hang(:\$, but onlyin that mo re problems are add,ed, fewer aresolve $<1 \sim$ and all become constantly more urgent. Fuelled by the explosion of the. world's population, the quest for asylum is one. of the most pressing problems of

our age. Refugee-receiving nations-located frequently, but by no means exclusively, in the Western world-have to respond to masses of humanity searching for new livable homes. Human compassion for these refugees can be found everywhere, but so Cat1 xeo,9phobia and the $\mathrm{d} \sim$ sire to pre e(Ve one's nation, econo.tnicwell beillg, and culrural.integtity. The dash betWeen these impulses represents one of the great dilemmas of our time and is the subject ofPlaut'ssrudy. In exploring it, he provides a farranging inquiry into the human condition.

The book presents political, ethnic, philosophical, religious, and sociological arguments, and deals with some of the most troublesome and heartbreaking conflicts in the news.

Contents: Thelssues;Questions Without Answers; Definitions; Religion, Natural Law, and Hospitality; A Look at History; Some Ethical Questions; Through the Lens of Sociobiology; Community and Individual; Contended Rights: To Leave, Rerum, Remain; The Practice; Refugees in Africa; Four A,sianLands; Glimpses ofEurQpe and Central Arnerica.;TheNorth American Experience; The Sanctuary Movement; A Final Look; Bibliography;Index.

Asylum-A Moral Dilemma is simultaneously published in the United States by Praeger Publishers) and in Canada by York Lanes Press.

$$
\text { Availablefrdm: }
$$

Centre for Refugee Studies Fax: (416) 736-5837 ${ }^{\bullet}$ Email: refuge@yorku.ca 